Оригинални научни рад

Rodoljub M. Etinski, Ph.D., Full Professor

University of Novi Sad

Faculty of Law Novi Sad

R.Etinski@pf.uns.ac.rs

\title{
THE INTERRELATIONSHIP BETWEEN THE EUROPEAN CONVENTION ON HUMAN RIGHTS AND THE AARHUS CONVENTION
}

\begin{abstract}
The Taşkın case manifests mutual supportiveness of the Aarhus Convention and the European Convention on Human Rights as well as of the general international environmental and the right to private and family life. Interactions between the protection of the environment and human rights are complex and involve economic and political factors. Legal concepts of sustainable development, mutual supportiveness and balance of interests bring new principles governing the complex interactions. They are reflected in Taşkin.
\end{abstract}

Keywords: human rights, protection of environment, sustainable development, mutual supportiveness, balance of interests.

\section{INTRODUCTION ${ }^{1}$}

By referring to the Convention on Access to Information, Public Partnership in Decision-Making and Access to Justice in Environmental Matters (hereinafter: the Aarhus Convention) in interpretation of the Convention for the Protection of Human Rights and Fundamental Freedoms (hereinafter: the European Convention on Human Rights or the ECHR) the European Court of Human Rights (hereinafter: the ECtHR) has established an interrelationship between the two conventions. For the time being, the interrelationship has manifested in a new content regarding the right to privacy, guaranteed by Article 8 of the ECHR and in increasing effectiveness of Articles 6 (8) and 9 (2) of the Aarhus Convention.

\footnotetext{
${ }^{1}$ The article has been prepared in the framework of the research project "Biomedicine, Protection of Environment and Law" No. 179079, financed by the Ministry of Education and Science of the Republic of Serbia. (Rad je pripremljen u okviru projekta „Biomedicina, zaštita životne sredine i pravo“ br. 179079 koji finansira Ministarstvo prosvete i nauke Republike Srbije.)
} 
Though the two conventions are human rights treaties, the ECHR is a human rights treaty of general application and the Aarhus Convention guarantees three specific human rights in environmental matters. The European Convention on Human Rights is based on the classic concept of understanding of a human right. The concept of a human right has been changed by the specific object and purpose of the Aarhus Convention. In spite of these and some other differences between the two conventions, they are in harmony and capable of mutual supportiveness.

The broader context of their interrelationship is the interrelationship between environmental law and human rights. In principle, environmental law and human rights provide each other indirect protection. Since the detrimental effects of pollution of the environment affect human rights, then consequently the prohibition of pollution protects not only the environment but also human rights. Protection of human rights can have positive effects on the environment in some cases. In fact the interactions between protection of the environment and human rights are very complex, involve a lot of varied interests and they are closely connected with economic and political issues.

The interrelationship between the two conventions will be explored as established in the Taşkın and Others v. Turkey case. The case reflects some elements of general concepts in relation to the protection of the environment and human rights. The article begins with a brief elaboration of the general concepts and continues by relevant references to the Aarhus Convention and the European Convention on Human Rights. Then, the case will be analyzed.

\section{CONCEPTS OF SUSTAINABLE DEVELOPMENT, MUTUAL SUPPORTIVENESS AND BALANCE OF INTERESTS}

The concepts of sustainable development, mutual supportiveness and balance of interests might be seen as the principles of new global governance, born in new understanding of global interdependence and, accordingly, new understanding of national interests, new rationality and new comprehension of justice. Awareness of global interdependence among human groups, national societies, and generations across economy, environment, human rights and security is visible in many international agreements. Even before the concepts were formulated in international documents, their spirit has appeared in the 1985 Vienna Convention for the Protection of the Ozone Layer and the 1987 Montreal Protocol. The 1992 UN Convention on Climate Change, the 1997 Kyoto Protocol and the 2015 Paris Agreement are fully based on the principles of new global governance.

The legal concepts of harmonization of plurality of competing interests coming from the protection of the environment, economy and human rights are synthesized in the principle of sustainable development. In Gabcikovo-Nagymaros 
Project the International Court of Justice states: "This need to reconcile economic development with protection of the environment is aptly expressed in the concept of sustainable development." 2 The Court attributes legal effect to the concept since, referring to it, invites the parties to the dispute to explore the effect of the power plant on the environment. Sustainable development had been invoked again in Pulp Mills on the River Uruguay where the Court observed that the balance between economic development and environmental protection is the essence of sustainable development. ${ }^{3}$ It might be noted that the Court used the term "reconcile" in the first case and the term "balance" in the second, terms which do not necessarily have the same meaning.

The International Court of Justice has not elaborated further on the principle and has not connected the principle with human rights. However, the satisfaction of human needs and aspirations were determined as a landmark of sustainable development in the 1987 report "Our Common Future" of the World Commission on Environment and Development. "The exploitation of resources, the direction of investments, the orientation of technological development and institutional change" have to be in harmony and to "enhance both current and future potential to meet human needs and aspirations." ration makes the substance of human rights.

Pavoni states that "the interpretative pillar of the principle of sustainable development" is the principle of mutual supportiveness. ${ }^{5}$ The raison d'etre of the principle is reconciliation of competing interests. ${ }^{6}$ Pavoni sees the principle also as an embryo of an obligation of States to cooperate in good faith in law making process to remove conflicts between agreements that cannot be resolved by interpretation.?

Barrett Lydgate prefers the concept of balance of interests. She writes: “... rather than mutual supportiveness (or its converse, mutual unsupportiveness), a more productive concept to characterize the relationship between sustainable development's pillars is that of balancing." ${ }^{8}$ Her point is that the concept of balancing

\footnotetext{
${ }^{2}$ Gabcikovo-Nagymaros Project (Hungary/Slovakia), Judgment, I. C. J. Reports 1997, para 140.

${ }^{3}$ Case concerning Pulp Mills on the River Uruguay (Argentina v. Uruguay) Judgment of 20 April 2010, para 177.

${ }^{4}$ Quoted by J. Verschuuren, Sustainable Development and the Nature of Environmental Legal Principles, PER/PELJ 1/2006, 2015, p. 215. See further on sustainable development at B. Tubić, Načelo održivog razvoja u međunarodnim pravnim aktima i praksi Međunarodnog suda, Zbornik radova pravnog fakulteta u Novom Sadu, 3/2013, pp. 391 - 410.

${ }^{5}$ R. Pavoni, Mutual Supportiveness as a Principle of Interpretation and Law-Making: A Watershed for the 'WTO-and-Competing-Regimes' Debate? European Journal of International Law, 3/2010, p. 662.

${ }^{6}$ Ibid., p. 666.

${ }^{7}$ Ibid., p. 666.

${ }^{8}$ E. Barrett Lydgate, Sustainable development in the WTO: from mutual supportiveness to balancing, World Trade Review, 4/2012, p. 622.
} 
helps not only when goals of sustainable development are in harmony but also when they are not and when it is necessary to prioritize some of them. ${ }^{9}$

Having decided to put the topic "Protection of the atmosphere" on its agenda and appointed Mr. Shinya Murase as Special Rapporteur, the International Law Commission (hereinafter: the ILC or the Commission) considered three reports and adopted provisionally several draft guidelines on the topic and commentaries thereto in the period 2014-2017.

Guideline 9 addresses an interrelationship between the rules of international law relating to the protection of the atmosphere and other relevant rules of international law. ${ }^{10}$ The guideline consists of three paragraphs. The first relates to identification, interpretation and the application of the rules of international law relating to the protection of the atmosphere and other relevant rules of international law..$^{11}$ The second is dedicated to development of all these rules. And the third requires that special consideration is given to persons and groups particularly vulnerable to atmospheric pollution and degradation when applying paragraphs 1 and 2.

The first paragraph instructs that the rules of international law relating to the protection of the atmosphere and other relevant rules of international law should "be identified, interpreted and applied in order to give rise to a single set of compatible obligations, in line with the principles of harmonization and systemic integration, and with a view to avoiding conflicts." It states further that the said operations have to be performed in accordance with the rules of the 1969 Vienna Convention on the Law of Treaties (hereinafter: the Vienna Convention) and in particular its Articles 30 and $31(3, \mathrm{c})$ and the principles and rules of customary international law. Among "other relevant rules of international law" the first paragraph distinguishes specifically "the rules of international trade and investment law, of the law of the sea and of international human rights law".

A commentary of the ILC on guideline 9 states that the arrangement of the interrelationship between the rules of international law relating to the protection of the atmosphere and other relevant rules of international law has its origin in the conclusions of the Study Group of the ILC on fragmentation of international law: difficulties arising from the diversification and expansion of international

\footnotetext{
${ }^{9}$ Ibid.

${ }^{10}$ RILC 2017, 155
}

${ }^{11}$ Paragraph 1 states: "The rules of international law relating to the protection of the atmosphere and other relevant rules of international law, including inter alia the rules of international trade and investment law, of the law of the sea and of international human rights law, should, to the extent possible, be identified, interpreted and applied in order to give rise to a single set of compatible obligations, in line with the principles of harmonization and systemic integration, and with a view to avoiding conflicts. This should be done in accordance with the relevant rules set forth in the Vienna Convention on the Law of Treaties of 1969, including articles 30 and 31, paragraph 3 (c), and the principles and rules of customary international law." 
law. The Study Group differentiates relationships of interpretation and relationships of conflict. The relationships of interpretation exist when "one norm assists in the interpretation of another" so that "both norms are applied in conjunction."12 The relationships of conflict occur where two applicable norms lead to incompatible decisions "so that a choice must be made between them."13 The text of the Study Group explains that a formula "a single set of compatible obligations" is expression of the principle of harmonization. The Study Group states further "when several norms bear on a single issue, they should, to the extent possible, be interpreted so as to give rise to a single set of compatible obligations". ${ }^{14}$

Two matters attract attention. The first relates to the distinction between relationships of interpretation and relationships of conflict. Does the distinction mean that relationships of conflict remain beyond interpretation and cannot be resolved by interpretation? We have seen that Pavoni thinks that such a situation can exist. It seems that the Study Group considers that relationships of conflict are regulated by a mechanism that secures harmony in the system of international law, consisting of jus cogens, Article 103 of the UN Charter and principles such as lex specialis or lex posterior. The second matter worth attention is that the ILC was inspired by the report of the Study Group in drafting guideline 9, but relationships of conflict were not addressed separately. Reference to Article 30 of the Vienna Convention in the first paragraph of guideline 9 discloses an opinion of the ILC that the text of paragraph 1 of guideline 9 encompasses resolution of relationships of conflict.

Considering the relationship between international environmental law and international trade law in the commentary of draft guideline 9, the ILC refers to "the concept of mutual supportiveness," designed to reconcile the two branches of international law. ${ }^{15}$ The Commission finds the concept in the preamble of the 1994 Agreement establishing the WTO, in documents of the WTO Committee on Trade and Environment and in the 2001 Doha Ministerial Declaration. The ILC discusses certain issues relevant regarding the impact of environmental pollution on human rights, but not the concept of mutual supportiveness in that context.

The reports of the ILC are limited to the interrelationship between the rules of international law relating to the protection of atmosphere and other rules of international law but the elaboration on the interrelationship is of general importance. The third paragraph of guideline 9 requiring special consideration for persons and groups particularly vulnerable to pollution and degradation is of particular importance.

\footnotetext{
12 YILC, 2006, vol. II, Part II, p. 178, para 251 (a, 2).

${ }^{13}$ Ibid.

${ }^{14}$ YILC, 2006, vol. II, Part II, p. 178, para 251 (a, 4).

${ }^{15}$ RILC, 2017, p. 157.
} 


\section{THE AARHUS CONVENTION}

The Aarhus Convention tends to satisfy a need and aspiration of an individual not only to live in a healthy environment but also to be informed on and active in the preservation of the environment. The mentioned human need and aspiration has been legally articulated through three particular rights in environmental matters: the right to information, the right to participation in decision-making and the right to justice.

It might be said that the Aarhus Convention has been created to provide mutual supportiveness between protection of the environment and human rights and that it brings really benefits to bear on the two branches of law - environmental law and international human rights law. The protection of the environment is becoming more democratic and effective. It is a valuable benefit for environmental law. On the other hand, the Aarhus Convention recognizes a new international human right of individuals and NGO-s to participate in decision-making and extends the right to justice almost to the scope of actio popularis. ${ }^{16}$ By adapting the three human rights to the specific characteristics of its object and purpose, the Aarhus Convention changes a standard concept of human rights in respect of two important aspects territorial jurisdiction and status of victim. The two issues are referred in the Report of the ILC related to Protection of atmosphere since the classic legal answers to them make obstacles for the establishment of interrelationship of mutual supportiveness between protection of atmosphere and protection of human rights. ${ }^{17}$ The Aarhus Convention has changed the answers and removed the obstacles.

The classic jurisdictional standard in regard to human rights restricts in fact responsibility of a State for human rights violation occurred on the territory of the State. A State is responsible effectively only for human right violation occurred on its territory or on the territory under its full jurisdiction. By departing from that jurisdictional standard, the Aarhus Convention reconciles the jurisdictional standard of human rights with the general rules of responsibility of States, according to which a State is responsible for any illegal act that can be attributed to it. Thus, under the Aarhus Convention the Party is responsible for its failure to satisfy an obligation, established by the Convention, not only to subjects under its jurisdiction but also to subjects on territories of other Parties. ${ }^{18}$

16 The Aarhus Compliance Committee considers that Article 9(3) does not oblige parties to provide actio popularis and that they can avoid actio popularis by employing criteria, such as "being affected or of having an interest" Belgium ACCC/2005/11; ECE/MP.PP/C.1/2006/4/Add.2, 28 July 2006, para. 35, Denmark ACCC/C/2006/18, ECE/MP.PP/2008/5/Add.4, 29 April 2008, para. 29, European Union ACCC/C/2008/32 (Part I), ECE/MP.PP/C.1/2011/4/Add.1, May 2011, para. 77.

${ }^{17}$ RILC 2017, p. 160.

${ }^{18}$ R. Etinski, Specific Features of Human Rights Guaranteed by the Aarhus Convention, Zbornik radova Pravnog fakulteta u Novom Sadu, 2/2013, pp. 84 - 86. 
Global 2000/Friends of the Earth Austria, an NGO based in Austria submitted a communication to the Compliance Committee in 2009, claiming that Slovakia was in breach of Article 6 of the Aarhus Convention, since it had not provided for public participation in the decision-making process for the construction permits related to some units of Mochovce nuclear plant. It was done in collaboration with Friends of the Earth Europe, Greenpeace Slovakia and International, Za Matky Zem and VIA IURIS. The Compliance Committee found that the communication was admissible and found some failures of the Respondent to comply with provisions of the Convention. ${ }^{19}$ Three NGOs - Greenpeace Slovakia, Via Iuris and GLOBAL 2000/Friends of the Earth Austria - submitted a new communication to the Compliance Committee in 2013 alleging the failure of Slovakia to comply with the Convention's provisions on public participation and access to justice. ${ }^{20}$ The Compliance Committee found again that the communication was admissible and that Slovakia failed to comply with some provisions of the Aarhus Convention. It should be noted that only Slovakian NGOs participated in internal proceedings. In spite of that the Compliance Committee recognized capacity of communicant to Austrian NGO. The legal ground for such approach might be found in Article 3 (9) of the Convention that secures enjoyment of the rights recognized by the Convention "without discrimination as to citizenship, nationality or domicile and, in the case of a legal person, without discrimination as to where it has its registered seat or an effective centre of its activities".

There are two circumstances of importance for interpretation of the Aarhus Convention in respect of the scope of its application. The clause standard for many human rights treaties according to which a State Party is obliged to secure the rights guaranteed by the treaty to all persons under its jurisdiction or on its territory does not appear in the Aarhus Convention. Another circumstance is that the Preamble of the Aarhus Convention refers to the 1991 Convention on Environmental Impact Assessment in a Transboundary Context, the 1992 Convention on the Transboundary Effects of Industrial Accidents and the 1992 Convention on the Protection and Use of Transboundary Watercourses and International Lakes. The transboundary context is a distinguished characteristic of the mentioned conventions. Having in view the text of Article 3 (9) of the Aarhus Convention and an absence of a territorial clause in it, transboundary context as the main feature of the objects of the referred conventions and the Global 2000/Friends of the Earth Austria v. Slovakia cases, the Aarhus Convention might be interpreted that

${ }^{19}$ Findings and recommendations with regard to communication ACCC/C/2009/41 concerning compliance by Slovakia, adopted by the Compliance Committee on 17 December 2010, p. 12, para 69. All findings and recommendations of the Compliance Committee are available at https:// www.unece.org/env/pp/cc/com.html.

${ }^{20}$ Findings and recommendations with regard to communication ACCC/C/2013/89 concerning compliance by Slovakia Adopted by the Compliance Committee on 19 June 2017. 
responsibility of a Party for compliance with the provision of the Convention is not restricted solely to the public on the territory of the Party.

A status of victim of an applicant is one of the standard conditions for admissibility of an application in the proceedings for protection of human rights. It is established, for example, by Article 34 of the ECHR or by Article 1 of the Optional Protocol to the International Covenant on Civil and Political Rights. The procedure for the review of compliance of the Parties with the Aarhus Convention as it is established by the Annex to Decision I/7 on review of compliance, adopted at the meeting of the Parties in 2002, does not ask the status of the victim as a condition for admissibility of communication. According to point 18 of the Annex "communications may be brought before the Committee by one or more members of the public..." Members of the public are individuals and NGOs. In the above passage it is stated that the status of communicant was recognized for an Austrian NGO that did not participate in internal proceedings. However, in internal procedures as provided by Articles 6 and 9 ( 2 and 3), conditions that an individual is affected or is likely to be affected, or to have interest, are or may be foreseen.

The Aarhus Convention is not a classic international human right agreement that guarantees some human rights in the area of legal protection of the environment. It is inspired by design of general utility that will flow from a mutual reinforcement of the protection of human rights and protection of environment.

\section{THE EUROPEAN CONVENTION ON HUMAN RIGHTS}

The ECHR is the first, classic, regional and the most effective international human rights treaty. The effectiveness of the Convention comes from the effectiveness of the European control mechanism as established by the Convention. ${ }^{21}$ The ECHR is a legislative, "open-texture" treaty. This characteristic is important in understanding its relationship with other international conventions, as established in the interoperation of the ECHR by the ECtHR. All issues of interpretation of the Convention will not be explored here but only these relevant in relation to the concept of mutual supportiveness. ${ }^{22}$

The evolutive interpretation is one of landmarks of the ECHR. ${ }^{23}$ The Convention was drafted in 1950. It goes without saying that in interim period the

${ }^{21}$ R. Etinski, S. Đajić, Direct effect of the European Convention on Human Rights, Annals of the Faculty of Law in Belgrade, 3/2015, pp. 93.

${ }^{22}$ See more on interpretative practice of the ECtHR in R. Etinski, Means of Interpretation of International Treaties and Determinants of Their Significance, Zbornik radova Pravnog fakulteta u Novom Sadu 4/2017, pp. 1191 - 1194.

${ }^{23}$ S.C. Prebensen, 'Evolutive interpretation of the European Convention on Human Rights', in P. Mahoney at al., (eds) Protecting Human Rights: The European Perspective, 2000, p. 1123; G. Letsas, The Truth in Autonomous Concepts: How To Interpret the ECHR, European Journal of 
European countries, as the Parties to the Convention, have changed and continue to change. The standards of human rights in national societies have advanced. The social development and progress of human right standards play an important role in the interpretation of the ECHR. The ECtHR noted that the Convention cannot be interpreted "solely in accordance with the intentions of their authors as expressed more that forty years ago" and "the Court cannot but be influenced by the developments and commonly accepted standards." ${ }^{24}$

The ECtHR uses plurality of sources to detect relevant development and new standards. International conventions, practice of the Parties, materials created in the Council of Europe and other international organizations, case law of other international courts and human rights bodies are among the sources. The ECtHR investigates those sources in search of common understanding of the Parties that the Court qualifies as a European consensus, broad consensus, widespread consensus, emerging consensus or common ground. Usually, consensus established in such a way plays a decisive role in the interpretation. It is not necessary that all Parties participate and accept consensus. Commonly, consensus among a majority is sufficient. The principle of effectiveness is also one of the important methods used by the ECtHR in interpreting the ECHR. The ECtHR has repeated many times that "that it is essential that the Convention is interpreted and applied in a manner which renders its rights practical and effective and not theoretical and illusory." 25

The ECtHR relies on Articles 31 - 33 of the Vienna Convention but, having in view specific characteristics of the ECHR, and that it serves as a constitutional instrument in European public order in the area of human rights, the ECtHR avails itself with some flexibility in application of the mentioned Articles. Thus, the ECtHR used the Aarhus Convention as the main instrument in interpretation of Article 8 of the ECHR in the Taşkın and Others v. Turkey ${ }^{26}$ in spite of the fact that Turkey is not a Party to the Aarhus Convention. However, the great majority of Parties to the ECHR are the Parties to the Aarhus Convention. Consequently, the

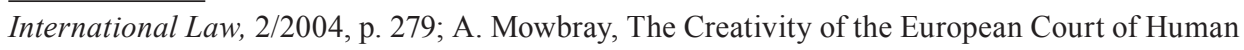
Rights, Human Rights Law Review, 1/2005, p. 57; C.L. Rozakis, The European Judge as Comparatist, Tulane Law Review, 2005 - 2006, p. 257; P.M. Dupuy, Evolutionary Interpretation of Treaties: Between Memory and Prophecy, in E. Cannizzaro (ed), The Law of Treaties Beyond the Vienna Convention, 2011, pp. 133-136, G. Letsas, Strasbourg's Interpretative Ethic: Lessons for the International Lawyer, European Journal of International Law, 3/2010, p. 509; K. Dzehtsiarou, European Consensus and the Evolutive Interpretation of the European Convention on Human Rights, German Law Journal, 10/2011, p. 1730.

${ }^{24}$ Loizidou v. Turkey, (app. no. 15318/89), Judgment of 18 December 1996, at paras. 71, 31. All ECtHR decisions are available online at http://hudoc.echr.coe.int/.

${ }^{25}$ Paposhvili v. Belgium, (app. no. 41738/10), Judgment of 13 December 2016, at para 182; Nada v. Switzerland, (app. no. 10593/08), Judgment of 12 September 2012, para. 195.

${ }^{26}$ Taşkın and Others v. Turkey (app. no. 46117/99) Judgment of 10 November 2004. 
Aarhus Convention is evidence of consensus among the majority of Parties. Or, in the Magyar Helsinki Bizottság v. Hungary case $^{27}$ the ECtHR uses the Council of Europe Convention on Access to Official Documents in the interpretation of Article 10 of the ECHR, which was ratified at that time by seven Parties to the ECHR including Hungary. Obviously, the seven Parties do not make a majority, although in that case it was just one of many sources consulted by the ECtHR and it did not have decisive importance.

It might however be observed that the method used in the last two cases does not go beyond the limits of Articles 31 - 33 of the Vienna Convention. The method could be qualified as a supplementary means of interpretation. The enumeration of supplementary means of interpretation in Article 32 is not exhaustive. Supplementary means encompass all means beyond these enumerated in Article 31 which include various sources and methods that provide information on the intention of the parties, on the understanding of the parties of the text of a treaty or on legal and factual circumstance that the court can use to answer a submitted question. In the last two cases, and it is frequently the case, the provisions of the ECHR are obscure in respect to the submitted question, they do not give a clear and precise answer. Hence, the use of supplementary means is quite justified.

The ECHR does not protect the right to adequate environment, but the ECtHR has accepted that acts of a Party concerning environment can breach human rights guaranteed by the Convention. ${ }^{28}$

\section{TAŞKIN AND OTHERS V. TURKEY: A RELATIONSHIP OF MUTUAL SUPPORTIVENESS}

The relationship between Articles 6 and 9 (2) of the Aarhus Convention and Article 8 of the ECHR as exists in Taşkın and Others v. Turkey ${ }^{29}$ will be explored. It might be said the established relationship between the mentioned provisions by the ECtHR manifests mutual supportiveness.

Article 6 of the Aarhus Convention governs public participation in decisions on specific activities listed in Annex I thereto. Article 9(2) of the Aarhus Convention is dedicated to the access to justice in respect of decisions made under Article 6 . Article 8 of the ECHR guarantees the right to respect for private and family life. The ECtHR has already found that Article 8 can be violated by failures of the Parties properly to apply environmental law. Thus it has already established

${ }^{27}$ Magyar Helsinki Bizottság v. Hungary, (app. no. 18030/11), Judgment of 8 November 2016.

${ }^{28}$ S. Đajić, Pravo na zdravu životnu sredinu i Evropski sud za ljudska prava, Pravni život, br.12, IV/2012, 277-290. I. Krstić, Zaštita životne sredine u jurisprudenciji Evropskog suda za ljudska prava, Pravni život, br. 9, I/ 2012, 645-661.

${ }^{29}$ See at f. 26. 
in its case law that Article 8 implies some procedural and substantial obligations of the Parties regarding environmental issues. The Taşkın and Others case relates to the participation of the public in the decision-making of the Turkish authorities concerning a permit for construction of a gold mine.

In paragraph 119 of the judgment, considering the procedural aspect of compliance of Turkey with Article 8, the ECtHR states: "...the individuals concerned must also be able to appeal to the courts against any decision, act or omission where they consider that their interests or their comments have not been given sufficient weight in the decision-making process."

The Taşkın case was not the first case where the ECtHR considers the procedural aspect of Article 8 of the ECHR in the context of environmental protection. The ECtHR explores the same issue in Hatton and Others v. The United Kingdom. ${ }^{30}$ Paragraph 128 of the judgment states inter alia: "The applicants and persons in a similar situation thus had access to the Consultation Paper, and it would have been open to them to make any representations they felt appropriate. Had any representations not been taken into account, they could have challenged subsequent decisions, or the scheme itself, in the courts." The difference between the Hatton case and the Taşkın case is remarkable. In the first case a judicial challenge of a decision is possible when any representation of the public has not been taken into account. In the second case an appeal to a court is possible when concerned individuals claim "that their interests or their comments have not been given sufficient weight in the decision-making process." "Sufficient weight" standard goes in favour of the individuals concerned and defines more seriously an obligation of a State authority in respect of the consideration of the interests and comments of the concerned individuals.

Article 6 (8) of the Aarhus Convention states: "Each Party shall ensure that in the decision due account is taken of the outcome of the public participation." Obviously, "due account" standard is broader and weaker that "sufficient weight". Article 9 (2) of the Aarhus Convention provides the qualified public with the access to justice "to challenge the substantive and procedural legality of any decision, act or omission subject to the provisions of article 6..."

The relevant interpretation of Article 6 (8) of the Aarhus Convention by the Aarhus Compliance Committee states that "the authority should be able to demonstrate how the comments were considered and why it did not follow the views expressed by the public" and "while it is impossible to accept in substance all the comments submitted ... the relevant authority must still seriously consider all the comments received." ${ }^{31}$ Serious consideration of all received comments might

${ }^{30}$ Hatton and Others $v$. The United Kingdom (app. no. 36022/97) GCh Judgment of 8 July 2003, para 128 .

${ }^{31}$ Findings and recommendations with regard to communication ACCC/C/2012/70 concerning compliance by the Czech Republic adopted by the Compliance Committee on 20 December 2013, para 61 . 
imply attribution of sufficient weight to them but it is not necessary exclusive mode of serious consideration.

The ECtHR did not explain in the Taşkın judgment in what way it utilizes the Aarhus Convention in interpretation of Article 8 of the ECHR. It did not refer to any provision of Articles $31-33$ of the Vienna Convention. The Aarhus Convention is referred in a rubric Law - "The relevant international texts on the right to a healthy environment" in the judgment together with the 1992 Rio Declaration on Environment and Development and Recommendation 1614 (2003) on Environment and Human Rights of the Parliamentary Assembly of the Council of Europe. The principle 10 of the Rio Declaration which is an embryo of the Aarhus Convention as well as a relevant part of the Recommendation is quoted. The content of the Aarhus Convention is summarized. No doubt that the invoked international texts and in particular the Aarhus Convention had an important role in the interpretation of Article 8 of the ECHR. The words "any decision, act or omission" from the quoted sentence from paragraph 119 of the Taşkın judgment appear by the same order in Article 9 (2) of the Aarhus Convention. The text of paragraph 119 of the judgment as whole is inspired by the Aarhus Convention. However, none of the invoked international texts require attribution of sufficient weight to the interests or comments of the public in the decision-making process.

For the explanation of an origin of the requirement concerning sufficient weight standard it might be useful to look at paragraph 119 as a whole. ${ }^{32}$ The first sentence instructs a State how to treat "complex issues of environmental and economic policy". Investigations and studies have to be taken that will predict and evaluate the effects of the planned activities. A fair balance between the various conflicting interests has to be reached if the activities could damage the environment and violate individuals' rights. The sentence reflects the present state of general international law as it has been established by the International Court of Justice in Pulp Mills on the River Uruguay and as it relates to an environmental impact assessment and the balance between economic activities and protection of

32 Paragraph 119 reads: "Where a State must determine complex issues of environmental and economic policy, the decision-making process must firstly involve appropriate investigations and studies in order to allow them to predict and evaluate in advance the effects of those activities which might damage the environment and infringe individuals' rights and to enable them to strike a fair balance between the various conflicting interests at stake (see Hatton and Others, cited above, $\S 128$ ). The importance of public access to the conclusions of such studies and to information which would enable members of the public to assess the danger to which they are exposed is beyond question (see, mutatis mutandis, Guerra and Others v. Italy, judgment of 19 February 1998, Reports 1998-I, p. 223, § 60, and McGinley and Egan v. the United Kingdom, judgment of 9 June 1998, Reports 1998-III, p. 1362, § 97). Lastly, the individuals concerned must also be able to appeal to the courts against any decision, act or omission where they consider that their interests or their comments have not been given sufficient weight in the decision-making process (see, mutatis mutandis, Hatton and Others, cited above, § 127)." 
environment as the substance of sustainable development. The second sentence emphasizes the importance of public access to the studies and information so that the public can assess the danger to which they are exposed. And the third sentence secures the right of individuals on judicial control over treatment of interests and comments of the public in the decision-making process. The second and third sentences are inspired by the Aarhus Convention.

The concept of fair balance is employed by the ECtHR in cases of conflict of legitimate interests, usually the private interest of an individual and the public interest of the community. In the Hatton case the ECtHR indicates that evaluation of relative weight of each interest is important for determination of fair balance. ${ }^{33}$ Definition of relative weight of interest can also be a matter of European consensus. In the absence of consensus, the Parties enjoy the margin of appreciation whose breadth depends on a number of factors. When "an individual's existence or identity is at stake" margin is restricted. ${ }^{34}$

Thus, according the ECtHR the existence or identity of individuals must have a particular weight in building fair balance between all involved interests. It is fully in line with the concept of sustainable development and with paragraph 3 of guideline 9 of the ILC's draft on the protection of the atmosphere.

The standard of sufficient weight, proclaimed in the Taşkın case, might have some bearing on the effect of Articles 6 (8) and 9 (2) of the Aarhus Convention in the Parties to the ECHR. When applying the domestic provisions, which implement Articles 6 (8) and 9 (2), national authorities are under double controls - the Aarhus Convention and the ECHR, it is the Aarhus Compliance Committee and the ECtHR. In such a situation they have to reach a higher standard of sufficient weight.

\section{CONCLUSION}

The Aarhus Convention and the ECHR are human rights treaties. The first convention is a specific convention on the three human rights in environmental issues, inspired by mutual supportiveness of environmental law and international human rights law. The new right to participation in decision-making is recognized and the right to justice has been extended almost to the scope of actio popularis. The second Convention is characterized by general application, evolutive interpretation and effectiveness. When drafting the ECHR, their creators did not have in view their application on environmental matters. Over time the ECtHR has extended its application to environmental activities of the Parties when they interfere in guaranteed human rights.

\footnotetext{
${ }^{33}$ Hatton and Others, para. 125.

${ }^{34}$ Evans v. The United Kingdom, (app. np. 6339/05), Judgment of 10 April 2007, para 77.
} 
Paragraph 119 of the judgment in the Taşkın case manifests mutual supportiveness of the two conventions and of international environmental law and international human rights law. It transfers the content of general obligations of States concerning the environmental impact assessment and the balance between economic interests and the protection of the environment, as the substance of sustainable development, into Article 8 of the ECHR on the right of private and family life. It also emphasizes the importance of public access to the studies and information on environmental issues and the importance of judicial control over the decision-making process that comes from the Aarhus Convention.

On the other hand, paragraph 119 establishes the standard of sufficient weight that national authorities have to attribute to the comments and interests of the public which has participated in the decision-making process concerning some environmental matters. National courts and ultimately the ECtHR control whether the national authorities attributed sufficient weight. The determination of relevant weight of involved interests can be a matter of a European cconsensus. In the case of absence of the European consensus, the Parties enjoy a margin of appreciation which is restricted when the existence or identity of individuals is threatened. The standard has been established as an element of a procedural obligation under Article 8 of the ECHR when it covers the environmental activities of the Parties.

The ECtHR referred to the Aarhus Convention in the Taşkın judgment and summarized its content. However, the standard of sufficient weight has not been explicated in relevant provisions of the Aarhus Convention in Articles 6 (8) and 9 (2) nor has it been proclaimed in jurisprudence of the Aarhus Compliance Committee. It comes out from the concept of fair balance, developed by the ECtHR to reconcile primarily a private interest of an individual and the public interest of a community.

When applying domestic provisions which implement relevant provisions of the Aarhus Convention, national authorities in countries that are the Parties to the Aarhus Convention and the ECHR are under the control of the two conventions, it is under control of the Aarhus Compliance Committee and the ECtHR. In such situations national authorities have to reach higher standard of sufficient weight. 
Др Родољуб М. Ейински, редовни йрофесор

Универзииетеи у Новом Саду

Правни факулиетеи у Новом Саду

R.Etinski@pf.uns.ac.rs

\section{Међусобни однос Европске конвенције о људским правима и Архуске конвенције}

Сажейак: Евройска конвенција о људским иравима и Архуска конвен-

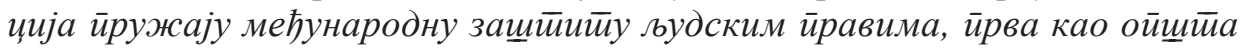
конвенција о људским ирравима, а друг̄a као сиечијализована за нека људска

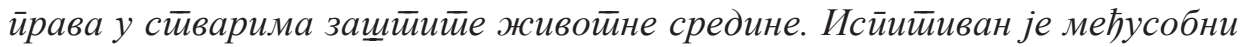
однос две конвениије како г̄а је Евройски суд за људска йрава усйосйавио у иредмейу Тащкин (Taşkın). Тумачећи члан 8 Евройске конвенције о људским иравима о йраву на ирривайности и размайрајући ироиесне обавезе које су овим чланом йредвићене за уг̄оворнище, Евройски суд за људска йрава се йозвао на одг̄оварајуће ирроиисе Архуске конвенције. Имајући у виду йоменуйе йройисе, обичајна ирравила о ирочени уитицаја на животину средину и своју

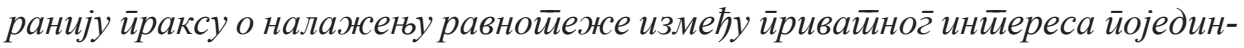
ияа и јавног̄ иниеереса заједнице, Евройски суд за људска йрава је усиостйавио стиандард одг̄оварајуће текеине, коју јавне властии уг̄оворница тиреба да йридају коменитарима и иниеересима јавностии у ирочесу одлучивања о йро-

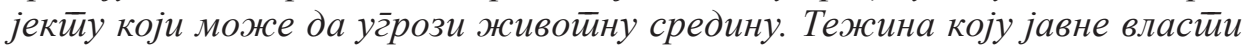

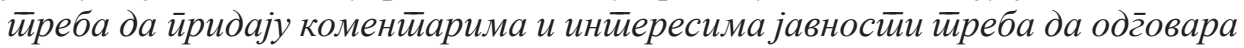

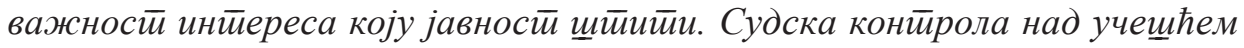

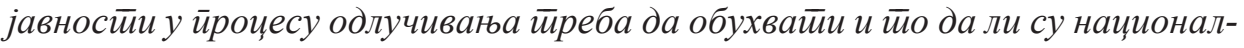

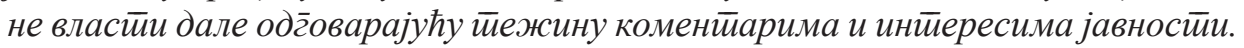
Евройски суд за људска йрава тиражи йако да уг̄оворнище йридају већи значај коменииарима и иниеересима јавностии у ирочесу одлучивања, иррощирује иииме садржај члан 8 Евройске конвенчије о људским ирравима већ и иовећава

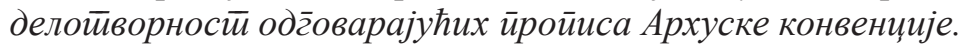

Кључне речи: људска йрава; зашимитиа живойне средине; одрживи развој; узајамна йодрика; равноиежжа иниеереса.

Датум пријема рада: 07.05.2018. 